\title{
EFEKTIFITAS LARUTAN UBI JALAR UNGU (IPOMEA BATATAS) \\ DENGAN BUAH NAGA BERDAGING MERAH (HYLOCEREUS POLYRHIZUS) SEBAGAI BAHAN IDENTIFIKASI PLAK (DISCLOSING SOLUTION)
}

\author{
Endah Aryati Ekoningtyas ${ }^{\varpi 1}$, Sekar Arum Sari ${ }^{2}$, Erni Mardiati ${ }^{3}$, Sulur Joyo Sukendro ${ }^{4}$
}

\begin{abstract}
ABSTRAK
Kandungan zat pewarna antosianin pada ubi jalar ungu dan kandungan zat pewarna karotenoid pada buah naga merah, berpotensi sebagai sumber bahan pewarna alami untuk melihat plak pada gigi. Tujuan penelitian ini dilakukan untuk mengetahui perbedaan kemampuan penggunaan larutan ubi jalar ungu dengan buah naga berdaging merah sebagai bahan identifikasi plak (disclosing solution) pada penghuni Asrama Bakti Husada Poltekkes Semarang.

Metode penelitian yang digunakan ini adalah Eksperimental Research. Desain yang digunakan adalah Posttest Only Design. Sampel diambil 30 orang dan dibagi 2 kelompok. Kelompok 1 berjumlah 15 orang diberikan perlakuan penetesan larutan ubi jalar ungu, dan kelompok II berjumlah 15 orang diberikan perlakuan penetesan larutan buah naga merah. Analisis data yang digunakan dalam penelitian ini adalah independent T-tes.

Hasil penelitian menunjukkan bahwa ada perbedaan antara larutan ubi jalar ungu dan buah naga berdaging merah. Rata - rata nilai indeks plak pada larutan ubi jalar ungu 2,221 dan rata-rata nilai indeks plak pada buah naga berdaging merah adalah 2,875. Hasil Uji Independet T-tes menunjukkan Sig 0,13 berarti terdapat perbedaan kemampuan penggunaan larutan ubi jalar ungu dengan buah naga berdaging merah sebagai bahan identifikasi plak ( $p<0,05)$. Berdasarkan hasil penelitian larutan buah naga merah lebih dapat mengidentifikasi plak dibanding dengan larutan ubi jalar ungu. Sehingga masyarakat disarankan untuk memanfaatkan larutan buah naga merah sebagai bahan alami untuk mengetahui ada tidaknya plak.
\end{abstract}

Kata Kunci : Ubi jalar ungu, Buah naga merah, Plak Indeks

\begin{abstract}
The content of the dye in purple sweet potato anthocyanins and carotenoids content of dyes in the red dragon fruit, has the potential a source of natural dyes. Plaque is usually formed on a third surface of the gingival and the tooth surface is rough, form biofilm, known as plaque. Plaque can absorb dyes that can indicate the presence of biofilm. The research objective was to determine differences in the ability of the solution to the purple sweet potato red fleshed dragon fruit as materials identification plaque (disclosing solution).

The method used is Experimental Research. Design used is Posttest Only Design. Samples were taken 30 people and divided into 2 groups. Group $1^{\text {st }}$ amounted to 15 people given treatment solution dripping purple sweet potato, and the second group totaled 15 people given treatment solution dripping red dragon fruit. Analysis of the data used in this study is Test Independent Test.

The results showed the averages value of the plaque index in a solution of purple sweet potato 2.221 and the average value of the plaque index in the red dragon fruit 2.875. Result of Independent T-test has Sig 0.13 means that there are differences in the ability to use the solution with a purple sweet potato red fleshed dragon fruit as materials identification plaque ( $p<0.05)$. As a material it is necessary to identify plaque dyes that can be embedded in dental plaque, antosianin amount of content that has the in herentability of the dye solution and based on research results more red dragon fruit can identify plaque compared with a solution of purple sweet potato.
\end{abstract}

Keywords: Sweet potato purple, red dragon fruit, Plaque Index

1,3,4) Dosen Jurusan Keperawatan Gigi Poltekkes Kemenkes Semarang

2) Mahasiswa Jurusan Keperawatan Gigi Poltekes Kemenkes Semarang

: endahsmg@yahoo.com 


\section{PENDAHULUAN}

Menurut Riskesdas 2013, terjadi peningkatan prevelensi karies aktif pada penduduk Indonesia dibandingkan tahun 2007 lalu, yaitu dari 43,4\% (2007) menjadi $53,2 \%$ (2013). Suatu peningkatan cukup tinggi jika dilihat dari kaca mata besaran kesehatan masyarakat. Dari sejumlah itu jika hasil Riskesdas 2013 menunjukkan prevelensi 53,2\% mengalami karies aktif. Penyebab utama terjadinya karies dan penyakit periodontal adalah plak gigi (Manson dalam Pratiwi 2014). Plak adalah suatu lapisan transparan yang melekat erat pada permukaan gigi (Armasastra dalam Pratiwi 2014).

Plak biasanya terbentuk pada sepertiga permukaan gingival dan pada permukaan gigi yang cacat dan kasar (Putri dkk, 2011). Pada permukaan gigi, koloni bakteri dapat berupa lapisan biofilm yang dikenal dengan plak. Secara umum komposisi plak meliputi mikroorganisme, matriks intraseluler yang terdiri dari komponen organik dan anorganik (Eley dkk, 2014 ).

Plak terdiri dari 20\% komponen padat dan $80 \%$ air. Komponen padat sebesar $70 \%$ adalah bakteri. Berdasarkan jumlah bakteri, plak terdiri dari karbohidrat dan protein yang meningkatkan perlekatan terhadap enamel dan berperan sebagai protective cover dan reservoir dari asupan nutrisi melalui proses metabolit. Jika plak tidak dihilangkan maka akan menjadi matang (struktur makromolekul memperkuat plak) dan meningkatkan perlekatan plak pada enamel gigi. Melalui endapan mineral yang terus menerus, plak kemungkinan akan berubah menjadi kalkulus (Fischer dalam Pratiwi 2014 ).

Untuk mengetahui volume atau banyak sedikitnya keberadaan plak, maka penilaian plak menggunakan indeks plak PHP. Menurut Putri dkk, (2011) indeks plak dapat dihitung berdasarkan jumlah permukaan indeks plak yang terjadi pewarnaan dari bahan identifikasi plak.
Semakin banyak pewarnaan yang terjadi pada permukaan gigi menandakan semakin banyak pula keberadaan plak pada permukaan gigi tersebut.

Ubi jalar ungu merupakan makanan tradisional yang memiliki manfaat bagi kesehatan. Ubi jalar ungu mempunyai komposisi gizi dan fisiologis yang bagus bagi kesehatan tubuh. Pigmen ungu pada ubi ungu bermanfaat sebagai antioksidan karena dapat menyerap polisi udara, racun, oksidan dalam tubuh dan menghambat penggumpalan sel-sel darah. Ubi jalar ungu mengandung senyawa antosianin yang berfungsi sebagai antioksida, antikanker, antibakteria, serta perlindungan terhadap kerusakan hati, jantung dan stroke. Jumlah kandungan antosianin bervariasi pada setiap tanaman dan berkisar antara $20 \mathrm{mg} / 100 \mathrm{gr}$ untuk 600 $\mathrm{mg} / 100$ gr berat basa (Siswoyo,2013).

Warna ungu pada ubi jalar disebabkan oleh adanya pigmen antosianin yang tersebar dari bagian kulit sampai ke daging umbinya (Apriyanto dalam Samber dkk, 2013) kandungan antosianin yang tinggi pada ubi jalar ungu mempunyai stabilitas yang tinggi dibanding antosianin dari sumber lain. Itulah sebabnya tanaman ini menjadi pilihan yang lebih sehat dan sebagai alternatif pewarnaan alami (Siswoyo, 2013).

Buah naga merah merupakan tanaman buah yang baru dibudidayakan di Indonesia dan banyak digemari oleh masyarakat karena memiliki khasiat dan manfaat serta nilai gizi cukup tinggi. Salah satu kandungan zat gizi dalam buah naga berdaging merah adalah zat karoten. Karoten adalah salah satu zat pewarna alami yang menghasilkan warna jingga sampai merah. Karena Buah naga mempunyai warna merah yang menarik, buah naga merah ini banyak di gunakan untuk alternatif pewarna alami dan bahan pewarna alami (Nur Hidayat, 2006). Menurut penelitian Basuki (2012) buah naga berdaging merah dapat digunakan sebagai bahan pewarnaan plak.

Berdasarkan latar belakang diatas, peneliti ingin mengetahui perbedaan kemampuan penggunaan larutan ubi jalar 
(Ipomea Batatas) dengan buah naga berdaging merah (Hylocereus polyrhizius) sebagai bahan identifikasi plak (Disclosing solution).

\section{METODE PENELITIAN}

Jenis penelitian ini adalah Eksperimental Research atau percobaan yang bertujuan untuk mengetahui suatu gejala atau pengaruh timbul sebagai akibat dari adanya perlakuan tertentu (Notoatmodjo, 2010). Desain penelitian yang digunakan dalam penelitian ini adalah Posttest Only Design.

Dalam penelitian ini yang menjadi populasi adalah mahasiswa Jurusan Keperawatan Gigi Penghuni Asrama Bakti Husada Poltekkes Semarang yang berjumlah 150 orang. Dalam penelitian ini besar sampel yang diambil $20 \%$ dari 150 orang yaitu 30 orang. Pemeriksaan pada 30 sampel dilakukan oleh 1 orang peneliti, dan 3 orang yang membantu penelitian, dimana tugasnya : satu orang membantu menyiapkan alat dan bahan, satu orang membantu mengarahkan responden untuk menggosok gigi, satu orang membantu menulis hasil pemeriksaan.

Pengumpulan data diperoleh dengan melakukan pemeriksaan indeks plak perlakuan larutan ubi jalar ungu dan buah naga berdaging merah pada responden Penghuni Asrama Bhakti Husada Poltekkes Semarang tahun 2014. Data yang dikumpulkan dilakukan observasi sesudah dilakukan perlakuan. Dalam penelitian ini sampel sebanyak 30 orang. Langkah-langkah penelitian yang dilakukan dalam pengumpulan data adalah sebagai berikut :

\section{Kunjungan pertama}

a. Menjelaskan perijinan kepada institusi bahwa akan dilakukan penelitian.

b. Menjelaskan tentang prosedur pelaksanaan penelitian dan tujuan dilaksankan penelitian.

c. Menjelaskan waktu pelaksanaan penelitian.

d. Menentukan sampel.
2. Kunjungan kedua

a. Melakukan perlakuan pada kelompok eksperimen dengan penetesan larutan ubi jalar ungu.

b. Mempersiapkan alat dan bahan untuk penelitian, dengan dibantu teman sejawat.

c. Mempersiapkan larutan ubi jalar ungu.

d. Memberikan instruksi kepada semua responden untuk menyikat gigi dengan teknik yang benar sebelum perlakuan. Setelah menyikat gigi didiamkan selama 7 menit.

e. Melakukan perlakuan pada responden dengan penetesan larutan ubi jalar ungu.

f. Memeriksa indeks plak gigi setelah seluruh permukaan gigi ditetesi larutan ubi jalar ungu.

g. Mencatat hasil pemeriksaan pada lembar pemeriksaan.

h. Pelaksanaan kegiatan menyikat gigi sendiri-sendiri.

3. Kunjungan ketiga

a. Melakukan perlakuan pada kelompok eksperimen dengan penetesan larutan buah naga berdaging merah.

b. Mempersiapkan alat dan bahan untuk penelitian, dengan dibantu teman sejawat.

c. Mempersiapkan larutan buah naga berdaging merah.

d. Memberikan instruksi kepada semua responden untuk menyikat gigi dengan teknik yang benar sebelum perlakuan, Setelah menyikat gigi didiamkan selama 7 menit.

e. Melakukan perlakuan pada responden dengan penetesan larutan buah naga berdaging merah.

f. Memeriksa indeks plak gigi setelah seluruh permukaan gigi ditetesi larutan buah naga berdaging merah.

g. Mencatat hasil pemeriksaan pada lembar pemeriksaan.

h. Pelaksanaan kegiatan menyikat gigi sendiri-sendiri. 


\section{HASIL DAN PEMBAHASAN}

Hasil penelitian tentang perbedaan kemampuan penggunaan larutan ubi jalar ungu dengan buah naga berdaging merah sebagai bahan identifikasi plak dilakukan pada penghuni Asrama Bakti Husada yang dilakukan terhadap 30 responden sebagai berikut ;

Tabel 1. Distribusi frekuensi kriteria Plak Indeks sesudah penetesan ubi jalar ungu

\begin{tabular}{llcc}
\hline \multirow{2}{*}{ No } & \multirow{2}{*}{ Kriteria } & \multicolumn{2}{c}{$\begin{array}{c}\text { Penetesan } \\
\text { ubi jalar ungu }\end{array}$} \\
\cline { 3 - 4 } & & $\mathrm{N}$ & $\%$ \\
\hline 1 & Baik $(0-1.7)$ & 2 & $13 \%$ \\
2 & Sedang $(1.8-3.4)$ & 11 & $74 \%$ \\
3 & Buruk $(3.5-5)$ & 2 & $13 \%$ \\
\hline & Jumlah & 15 & $100 \%$ \\
\hline Rata-rata & \multicolumn{2}{c}{2,221} \\
\hline
\end{tabular}

Dari Tabel 1 dapat dilihat bahwa plak indeks sesudah penetesan larutan ubi jalar ungu pada kelompok 1 yang paling tinggi persentasenya yaitu pada kriteria sedang dengan jumlah 11 responden (74\%).

Tabel 2. Distribusi frekuensi kriteria Plak Indeks sesudah penetesan larutan buah naga berdaging merah

\begin{tabular}{llcc}
\hline \multirow{2}{*}{ No } & \multicolumn{1}{c}{ Kriteria } & \multicolumn{2}{c}{$\begin{array}{c}\text { Penetesan } \\
\text { buah naga merah }\end{array}$} \\
\cline { 3 - 4 } & & $\mathbf{N}$ & $\mathbf{\%}$ \\
\hline 1 & Baik $(0-1.7)$ & 0 & $0 \%$ \\
2 & Sedang $(1.8-3.4)$ & 12 & $80 \%$ \\
3 & Buruk $(3.5-5)$ & 3 & $20 \%$ \\
\hline & Jumlah & 15 & $100 \%$ \\
\hline & Rata-rata & \multicolumn{2}{c}{2,875} \\
\hline
\end{tabular}

Dari Tabel 2 dapat dilihat bahwa plak indeks sesudah penetesan larutan buah naga berdaging merah pada kelompok 2 yang paling tinggi persentasenya yaitu pada kriteria sedang dengan jumlah 12 responden $(80 \%)$.
Tabel 3. Nilai rata-rata indeks plak sesudah penetesan larutan ubi jalar ungu dan buah naga berdaging merah

\begin{tabular}{cccc}
\hline Larutan ubi jalar ungu & \multicolumn{2}{c}{$\begin{array}{c}\text { Buah naga berdaging } \\
\text { merah }\end{array}$} \\
\hline $\mathrm{N}$ & Mean & $\mathrm{N}$ & Mean \\
\hline 15 & 2,221 & 15 & 2,875 \\
\hline
\end{tabular}

Dari data diatas dapat dilihat bahwa 15 responden yang diperiksa ditetesi larutan ubi jalar ungu didapatkan nilai rata-rata indeks plak sebesar 2,221, dan setelah ditetesi larutan buah naga merah didapatkan nilai rata-rata indeks plak sebesar 2,875. Untuk nilai selisih yaitu pada skor 0,654 merupakan nilai selisih antara melihat plak menggunakan ubi jalar ungu dan melihat plak menggunakan buah naga berdaging merah.

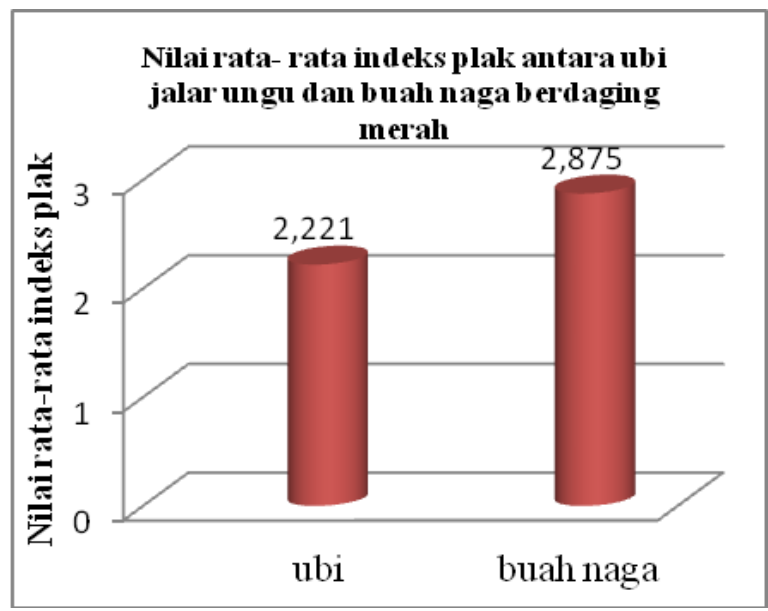

Gambar 2. Nilai rata-rata plak indeks sesudah perlakuan dengan ubi jalar ungu dan buah naga berdaging merah

Berdasarkan Gambar 2 dapat dilihat bahwa terjadi perbedaan nilai rata-rata indeks plak antara perlakuan dengan ubi jalar ungu dengan buah naga merah sebesar 0,654. Dilihat dari nilai rata-rata setelah dilakukan perlakuan dengan ubi jalar ungu dan buah naga merah, dapat disimpulkan bahwa untuk melihat plak pada gigi, ubi jalar ungu tidak bisa disamakan dengan buah naga merah karena terdapat selisih nilai indeks plak. 
Hasil Uji Independet t-Tes tentang perbedaan kemampuan penggunaan larutan ubi jalar ungu dengan buah naga berdaging merah sebagai bahan identifikasi plak menunjukkan $\mathrm{F}=0,034$ dengan Sig 0,13 berarti terdapat perbedaan kemampuan penggunaan larutan ubi jalar ungu dengan buah naga berdaging merah sebagai bahan identifikasi plak $(\mathrm{p}<0,05)$.

Bahan yang digunakan untuk melihat plak adalah dengan menggunakan zat warna. Bahan pewarna yang biasa digunakan adalah iodine, mercurochrome, bahan pewarna makanan, dan Bismarck brown (Pintaulli dan Hamada dalam Pratiwi, 2010). Setelah dilakukan eksperimen dengan ubi jalar ungu dan buah naga berdaging merah, didapatkan selisih sebesar 0,654. Selisih tersebut disebabkan zat warna antosianin dalam ubi jalar ungu mempunyai stabilitas yang rendah. Pada pemanasan yang tinggi, kestabilan dan ketahanan zat warna antosianin akan berubah. Selain mempengaruhi warna antosianin, $\mathrm{pH}$ juga mempengaruhi stabilitas zat warna antosianin. Antosianin lebih stabil dalam suasana asam (1-2) daripada dalam keadaan alkalis ataupun netral. Zat warna antosianin juga tidak stabil, dengan adanya oksigen dan asam akrobat (Winarno dalam Samber,dkk, 2013). Namun karena pH plak sekitar 4 - 9,5 sehingga antosianin kurang efektif dalam $\mathrm{pH}$ tersebut, sehingga warna larutan ubi jalar ungu sedikit menempel pada plak. Sedangkan zat warna karotenoid yang terkandung dalam buah naga berdaging merah, merupakan senyawa yang tidak larut dalam air dan sedikit larut dalam minyak atau lemak (Rao,dkk dalam Mutiara, 2013). Sehingga warna larutan buah naga berdaging merah dapat lebih menempel pada plak. Dari hasil penelitian ini dapat diketahui bahwa ubi jalar ungu dan buah naga berdaging merah dapat dijadikan untuk melihat plak pada gigi, tetapi terdapat perbedaan nilai indeks plak antara ubi jalar ungu dan buah naga berdaging merah.

\section{KESIMPULAN}

Berdasarkan hasil penelitian serta pembahasan tentang perbedaan kemampuan penggunaan larutan ubi jalar ungu dengan larutan buah naga merah sebagai bahan identifikasi plak (Disclosing solution ) pada penghuni Asrama Bakti husada Poltekkes Semarang dapat disimpulkan sebagai berikut dari hasil penelitian bahwa terdapat perbedaan antara larutan ubi jalar ungu dengan larutan buah naga berdaging merah sebagai bahan identifikasi plak (disclosing solution).

\section{SARAN}

Berdasarkan hasil penelitian diatas, maka peneliti memberikan saran sebagai berikut : perlu dilakukan penelitian lain lebih lanjut dengan menggunakan metode penyimpanan yang lebih tepat agar sediaan tidak menunjukkan perubahan kandungan zat aktif.

\section{DAFTAR PUSTAKA}
Agus Riyanto, 2011, Aplikasi Metodologi Penelitian Kesehatan, Muha Medica, Yogyakarta.

Arikunto, Suharsimi, 2002, Prosedur Penelitian Suatu Pendekatan Praktek, Rineka Cipta, Jakarta.

Basuki, WD., 2012, Efektifitas Buah Naga Berdaging Merah Sebagai Pengganti Disklosing Solution untuk Melihat Plak, KTI, Poltekkes, Semarang.

Donna, P, 2007, Gigi Sehat merawat gigi sehari-hari, Buku Kompas, Jakarta

Khaldun, I., Erlidawati, dan Munzair, 2013, Kestabilan zat warna alami dan umbi ketela ungu. Chima Didactica Acta 1(1) $.34-40$. 
Kristanto, Daniel, 2009, Buah Naga Pembudiyaan di Pot di Kebun, Penebar Swadaya, Jakarta.

Notoatmojo, S., .2010, Metodologi penelitian kesehatan, Renika Cipta, Jakarta.

Pratiwi, A I., 2014, Manfaat Berkumur Sari Buah Delima Merah Terhadap Penurunan Akumulasi Plak. Skripsi Unmas

Putri, M.H., Herijulianti E, Nurjanah N., 2011. Ilmu Pencegahan Penyakit Jaringan Keras dan Jaringan Pendukung Gigi, EGC, Jakarta.

Riyanto, A., 2011, Aplikasi Metodeologi Penelitian Kesehatan, Muha Medica, Yogyakarta.

Rukmana, R., 1997, Budidaya dan pascapanen ubi jalar, Kanisius, Jogjakarta.

Saifudin, Aziz, Viesa., 2011, Standardisasi Bahan Obat Alam, Graha Ilmu, Yogyakarta.

Samber NL, Semangun H., Prasetyo B., 2013, Ubi Jalar Ungu Papua Sebagai Sumber Antioksidan. Jurnal, Fjip, uns. ac. id/index. Php/ probio/ article /view /3210.di akses pada tanggal 9 Desember 2014.

Santoso w, Teti Estiasih., Kopigmentasi Ubi Jalar Ungu (Ipomea Batatas var.Ayamurasaki) Dengan Kopigmen Na-Kaseinat Dan Protein Whey Serta Stabilitasnya Terhadap Pemanasan. 2014. 2(4).127-127

Sarwono, B., 2005, Ubi Jalar Cara Budi Daya yang Tepat Efisien dan Ekonomis Seni Agribisnis, Jakarta, Penerbit Siuaelaya.
Siswoyo, R., 2013, Tumpas Penyakit Dengan Buah dan Sayuran Warna Ungu, Jakarta, Penerbit Sakti, Swadaya: Jakarta.

UU RI N0.36 Tahun 2009 Pasal 93 ayat 1 .http:www.jkn.kemnkes.go.id., diakses pada 21/10/2014 